\title{
Two Old Prussian fragments
}

\author{
Frederik Kortlandt
}

Beside the Old Prussian corpus which was codified by Trautmann (1910, 1970, facsimile in Mažiulis 1966), there are a number of fragmentary texts (cf. Mažiulis 1981: 62-64), two of which are of major importance for the prehistory of the Baltic languages. These are an epigram (cf. Mažiulis 1975 and Schmalstieg 1976: 87-90, 93-97) and a proverb (cf. Sjöberg 1969). It appears that both texts represent the Pomesanian dialect of Prussian attested in the Elbing Vocabulary, the vowel system of which can be analyzed as follows (cf. Levin 1974: 5):

$\begin{array}{llll}\text { /i:/ } & \mathbf{i}, \mathbf{y} & / \mathrm{i} / & \mathbf{i}, \mathbf{e} \\ / \ddot{a}: / & \mathbf{e} & / \ddot{a} / & \mathbf{e}, \mathbf{a} \\ / \stackrel{a}{/} / & \mathbf{o}, \text { oa } & / a ̊ / & \mathbf{a}, \text { oa, e } \\ \text { /u:/ } & \mathbf{u} & / \mathrm{u} / & \mathbf{u}, \mathbf{o}\end{array}$

Writing $\bar{\imath}, \bar{e}, \bar{o}, \bar{u}$ for the long vowels and $\imath, e, a, u$ for the short vowels, I reproduce the two short texts here with my own transcription and translation:

\section{A Prussian Epigram (1369)}

Kayle rekyse. thoneaw labonache thewelyse. Eg. koyte. poyte. nykoyte. pe`nega doyte.

Kaile rikīs, tu ni jau labōnas tēwelis, Ik kwai tu pōtwei, ni kwai tu penega dōtwei.

Hello, mister! you are no longer a nice little uncle! If you want to drink, you do not want to give a penny! 


\section{A Prussian Proverb (1583)}

\section{Deues: does dantes, Deues does geitka.}

Deiwas dōs dantins, Deiwas dōs geitka.

God give teeth, God give bread.

My interpretation of the forms differs from earlier ones on the following points:

1. The timbre of the root vowel -e- in rekyse suggests that the original pretonic long vowel of ${ }^{*}$ rikijas was shortened at an early stage. This idea is supported by the timbre $-e$ - in the 1st catechism, where we find rekis, acc. rekian. The word is evidently a derivative of $r i k i$ 'Reich', which was borrowed from Germanic.

2. thoneaw may represent three syllables $t u$ ni jau. ${ }^{1}$

3. labonache may contain the suffix *-ann-, cf. Lith. geltónas 'yellow', Russ. velikán 'giant'.

4. The timbre e- of $\mathbf{E g}$ suggests a short vowel in $i k$.

5. I take koyte to be identical with Quoi tu 'wilstu' in the Enchiridion. The verb form is athematic and may represent the original perfect stem of Lith. kviẽsti 'to invite' (cf. Kortlandt 1989: 110).

6. poyte and doyte represent the infinitives potwei and dotwei (cf. Kortlandt 1990).

7. I agree with Schmalstieg against Mažiulis that pe^nega is a gen.sg. form to be identified with the corresponding East Baltic and Slavic forms.

8. This view is supported by the gen.sg. form geitka in the proverb (cf. Kortlandt 1988: 93).

${ }^{1}$ This renders the two lines isosyllabic. One could suggest the following metrical interpretation:

Kaile rikīs, tu ni jau labōnas tewēlis, Ik kwai tu pōtwei, ni kwai tu penega dōtwei. $-\smile-\smile \smile \smile \smile \smile \smile \smile$ Alternatively, one could suggest:

Kaile rikīs, tu ni jau labōnas tewēlis, Ik kwai tu pōtwei, ni kwai tu penega dōtwei.

In either case, the interpretation of thewelyse as ${ }^{*} t e w e$ lis is questionable. 
9. I take the form does to be neither a future nor a preterit but an aorist subjunctive (cf. Kortlandt 1982: 8). This formation is found as an imperative in the Enchiridion, e.g. Teiks 'stelle'.

Thus, I think that these two short texts offer a number of important clues to the prehistoric development of the phonology and morphology of the Baltic languages. There are a number of points which remain bothersome, however. In particular, the epigram offers the following problems:

1. Case forms seem to be mixed up in Kayle rekyse, where we should expect †Kayles rekye vel sim., cf. Kayles and rickie in other fragments (Mažiulis 1981: 64, 63).

2. The final - $e$ of rekyse, labonache, thewelyse suggests that the scribe was not a native speaker of Prussian and perhaps had an optional $-e$ (shwa) in his own speech. ${ }^{2}$

3. The spelling - ch- in labonache also points to a scribe who was not a native speaker of Prussian and may have perceived the Prussian ${ }^{*} s$ as very different from his own because it was not opposed to a velar fricative.

4. The vocalism of poyte and doyte seems to reflect a form of umlaut which is alien to the Prussian language.

5. The vowel reduction in the final syllables of koyte, nykoyte, poyte, doyte is also unexpected for a native speaker of the language.

6. The interpunction of the second line is highly remarkable and suggests that it was dictated to the scribe.

It therefore seems probable to me that the text was written by a German scribe who noted down the words of a Prussian colleague.

\footnotetext{
${ }^{2} \mathrm{Cf}$. the text Jesus ich leid for leide in the accompanying drawing.
} 


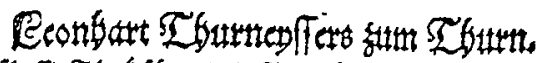

I4I.

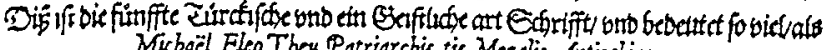
Misbäll Eleo Tbes Patriarchic tis Megalis Antiocbins.

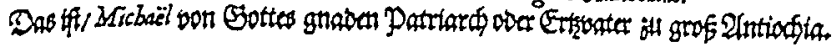

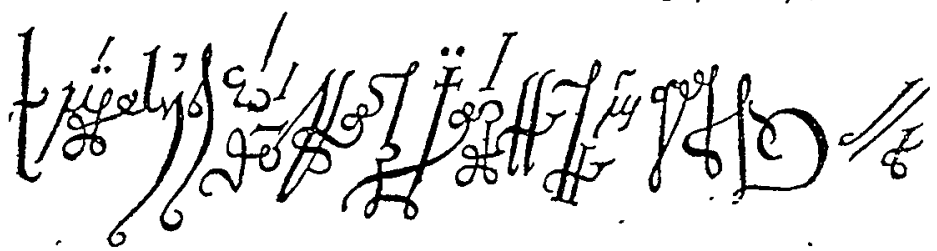

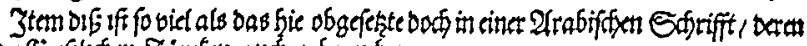

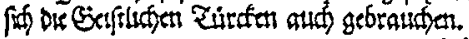

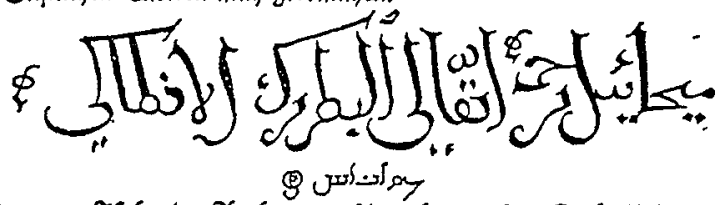

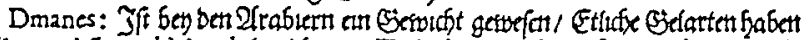

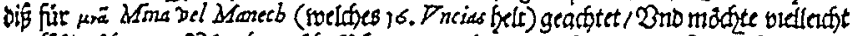

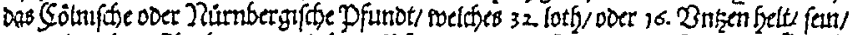

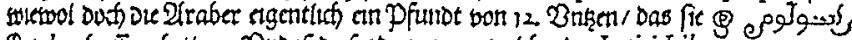

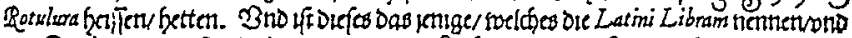

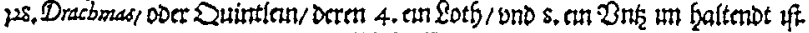
DAPRPIII:

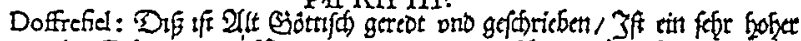

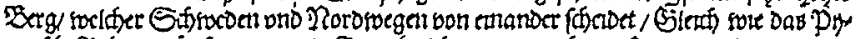

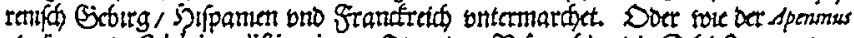

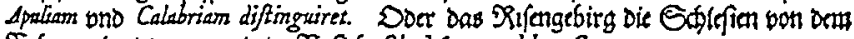

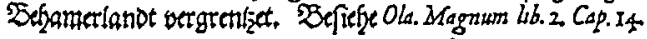

$$
\therefore \text {;? }
$$

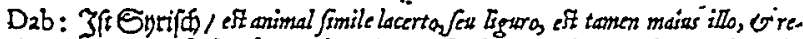

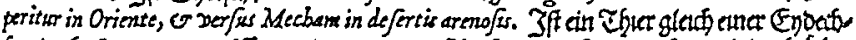

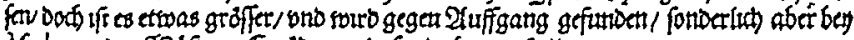

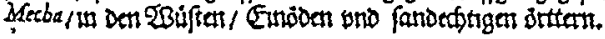

DE VES.

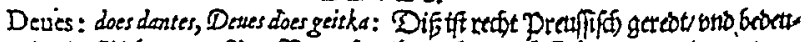

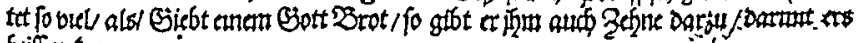
feifin tan.

DPT?

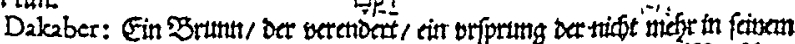

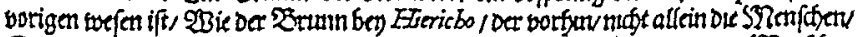

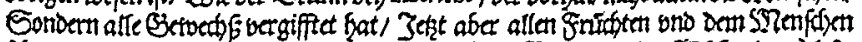

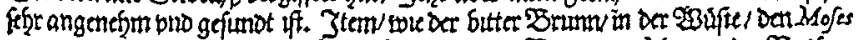

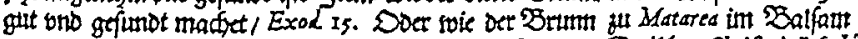

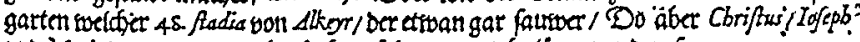

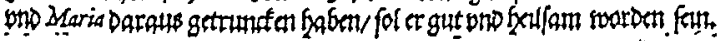

$$
\because \quad, \quad \cdots \text { ?Al. }
$$




\section{References}

Kortlandt, F. 1982: Innovations which betray archaisms. Baltistica 18/1, 4-9.

Kortlandt, F. 1988: Van Wijk's Altpreussische Studien revisited. Nicolaas van Wijk (1880-1941): Studies in Slavic and general linguistics $12,89-97$.

Kortlandt, F. 1989: Lithuanian statýti and related formations. Baltistica $25 / 2,104-112$.

Kortlandt, F. 1990: Old Prussian infinitives in -ton and -twei. Symposium Balticum: A Festschrift to honour Professor Velta RūkeDravina: 213-218. Hamburg.

Levin, J.F. 1974: The Slavic element in the Old Prussian Elbing Vocabulary. Berkeley and Los Angeles.

Mažiulis, V. 1966: Prūsı̨ kalbos paminklai. Vilnius.

Mažiulis, V. 1975: Seniausias baltų rašto paminklas. Baltistica 11/2, 125-131.

Mažiulis, V. 1981: Prūsų kalbos paminklai II. Vilnius.

Schmalstieg, W.R. 1976: Studies in Old Prussian. University Park and London.

Sjöberg, A. 1969: Ob odnoj drevneprusskoj poslovice. Scando-Slavica $15,275-276$.

Trautmann, R. 1910, 1970²: Die altpreussischen Sprachdenkmäler. Göttingen.

Cobetstraat 24

NL-2313 KC Leiden

[Abbildung S. 118 aus: München BSB, 2 Alch. 12/1.] 